DOI : $\underline{\text { https://10.24260/khatulistiwa.v9i2.1481 }}$

\title{
THE IMPLEMENTATION OF SUPREME COURT \\ REGULATIONS NUMBER 1/2016 CONCERNING THE PROCEDURE OF IN-COURT MEDIATION ON ECONOMY SHARIA DISPUTE (A CASE STUDY IN BLITAR RELIGIOUS COURT)
}

\author{
Kutbuddin Aibak \\ IAIN Tulungagung (backayback77@gmail.com) \\ Ahmad Musonnif \\ IAIN Tulungagung (sonetless@gmail.com)
}

\section{HIGHLIGHT}

- The sharia economic dispute resolution process in Indonesia has two paths can be taken by litigation in court and non-litigation

ARTICLE HISTORY

$\begin{array}{lll}\begin{array}{l}\text { Submit } \\ \text { Revision }\end{array} & : & \text { 30 June } 2019 \\ \begin{array}{l}\text { Revision } \\ \text { Minor }\end{array} & : & \text { 2 } 2 \text { July } 2019 \\ \begin{array}{l}\text { Accepted } 2019 \\ \text { Published }\end{array} & : & \text { 20 Sept } 2019 \\ & \text { 28 Sept } 2019\end{array}$

\begin{abstract}
The sharia economic dispute resolution process in Indonesia has two paths which can be taken by litigants, namely litigation in court and non-litigation. This research was motivated by sharia economic dispute cases handled by Blitar Religious Court which were carried out through a mediation but failed. The failure of this mediation process and the factors behind the failure are important issues to be studied. Consequently, Supreme Court Regulation No. 1/2016 becomes important to be used as the basis of analysis, whether this regulation has been implemented or not. Therefore, this study aims to describe and analyze the implementation of the Supreme Court Regulation Number 1/2016 concerning the procedure of in-court mediation on economy sharia disputes in Blitar Religious Court, along with various obstacles and solutions.
\end{abstract}

\section{Keywords; PERMA No. 1/2016, Sharia Economic Disputes, Mediation}

Copyright@2019 The Authors. Published by The Institute for Research and Community Service Pontianak State Institute for Islamic Studies This is an Open Access article under of CC BY-NC-ND 4.0 License https://creativecommons.org/licenses/by-nc-nd/4.0

KHATULISTIWA: Journal of Islamic Studies Vol. 9. No. 2 September 2019
DOI: https://10.24260/khatulistiwa.v9i2.1481-

The Implementation of Supreme Court

Regulation... 


\section{A. INTRODUCTION}

The task inherent in the court is providing solutions to various problems that are encountered or faced by the community. However, the existence of this judiciary in some cases still needs to be questioned, because in reality the parties who are litigating (the public) still have not received justice or a minimum of satisfaction with the prescribed decision. Consequently, over a number of weaknesses in this institution, both directly and indirectly, made the community choose another alternative in solving the problem. Moreover, in reality, the existence of non-court settlement institutions has also been numerous and has legal force.

Efforts that can be taken by the community in finding solutions to problems faced outside the court can be done through negotiation, mediation, and arbitration. Negotiation is an effort to resolve problems faced and carried out by parties who are in trouble. Mediation is a problem-solving process involving third parties (Abdul Manan, 2005). In general, this arbitration is a way to solve problems that do not go through a court which has been well known to the public (Fuady, 2003). However, from the perspective of the court, mediation is the choice of the community in resolving the dispute, because mediation has a neutral nature and the conflicting parties can choose their own expected solutions.

In relation to reconciling efforts between the parties through the litigation, the court has actually done it, which in this case is the responsibility of a judge, which is carried out before the case is examined. However, this effort can be said not fulfilled expectations. Therefore, the Supreme Court issued Circular Number 1/2002 and the following year a Supreme Court Regulation (PERMA) Number 2/2003 was issued which contained mediation procedures in court. Matters relating to this mediation procedure include the stage before mediation is carried out, the mediation itself and the place where the mediation is carried out and the costs to be paid.

KHATULISTIWA: Journal of Islamic Studies Vol. 9. No. 2 September 2019
DOI: https://10.24260/khatulistiwa.v9i2.1481-

The Implementation of Supreme Court Regulation... 
Efforts to improve the regulation continue to be carried out by the Supreme Court, by issuing PERMA No. 1/2008 which replaced the previous regulation, wherein this regulation the Supreme Court tried to provide something more complete and comprehensive. Then in 2016, the Supreme Court issued a new regulation perfecting the previous regulations. The things that are regulated in this regulation are new and there are some which are changes in relation to the implementation of mediation, as well as matters of a technical nature. The change or replacement is certainly in order to provide full service to the community in order to find solutions to the cases.

In addition, there were various criticisms addressed to this court due to several reasons, including the process through which the court seemed slow, formalistic, technical, expensive, and there were many cases handled in court (Mahkamah Agung RI, 2004). In reality, the solution given by the court is black and white, win-lose, which in the end one of the litigants feels aggrieved (Harahap, 2004). These problems make the Supreme Court provide a policy to unite mediation as part of the process of resolving litigation parties in court with non-litigation channels. This is because the mediation is wide open for litigants to find their own solutions with the help of neutral third parties. In this mediation process, the task of the mediator is nothing else but to motivate the parties to be inclusive, to deliberately find the best solution (Umam, 2010).

Therefore, in 1999 a mediation regulation was issued for the first time in the form of legislation concerning arbitration and alternative disputes. This is because mediation is an effort to resolve disputes that are considered to promote justice and satisfaction for litigants, and are effective and efficient and do not take a long time. Moreover, with this mediation the number of cases in the court can be reduced, as well as the duties of a judge can be maximized and optimized. Even though in reality this regulation was finally improved again, both in 2003 and 2008, it turned out that it had not provided a better impact on the mediation process.

Subsequent developments also occur in the authority of the Religious Courts, where the latest authority contained in this court is related to the Islamic economic sector as stated in Law No. 3 of 2006, where this law is a change from the previous law, namely Law No. 7 /1989. That is, with this change, the Religious Courts have the right and authority to carry out checks, terminations, and resolutions of sharia economic

DOI: https://10.24260/khatulistiwa.v9i2.1481-

The Implementation of Supreme Court Regulation... 
disputes. This is as stated in Law No. 3/2006, and also regulated in Law No. 21/2008 and Circular Letter No. MA. 8 in 2008.

The sharia economic dispute resolution process in Indonesia has two paths which can be taken by litigants, namely in-court litigation and non-litigation. The Religious Court is a judicial institution that has absolute authority to process sharia economic dispute issues. As the principle of Islamic personality and statutory provisions, Law No. 3/2006. Whereas the second line, the non-litigation pathway is an alternative form of dispute resolution and arbitration. This non-litigation path is a dispute resolution process carried out outside the court by means of consultation, negotiation, mediation, conciliation and judgment expert, as stated in Law No. 30/1999 article 1 number 10.

If further explored, the development of Islamic economics in East Java, specifically related to Islamic banking is so rapid, including in this case is Blitar District. There are many non- Islamic financial institutions that have sprung up and developed. Even conventional financial institutions also open sharia-based branches, such as BRI Syariah, BNI Syariah, Bank Syariah Mandiri, and so on. Sharia financial institutions which are so rapidly developing are certainly because they are supported by the community, in the sense that many people request and make transactions. Because of this development, there may be cases of sharia economics, even though in reality the efforts to resolve disputes through the court are still very rare because litigants prefer the ways outside the court. This is as occured in the new Blitar Religious Court, in which there is only one case of sharia economy (sharia banking) which is handled (Document No. 3333/Pdt.G/2014/PA.BL).

The occurance of several cases of dispute resolution in the Religious Court, especially sharia economic disputes in the Blitar Religious Court is interesting to be studied further. Therefore, this study is devoted to the resolution of sharia economic disputes through non-litigation channels, namely mediation in accordance to Supreme Court Regulation No. 1/2016 concerning Procedure for Mediation in Courts. Based on description context research above, author interested to conduct the research entitled "The Implementation of Supreme Court Regulations Number 1/2016 concerning Procedure of Mediation at Court on Dispute Economy Sharia (Case Study in Blitar Religious Court)".

KHATULISTIWA: Journal of Islamic Studies Vol. 9. No. 2 September 2019
DOI: https://10.24260/khatulistiwa.v9i2.1481-

The Implementation of Supreme Court Regulation... 
The formulation of the research problem is that How is the implementation of Supreme Court Regulations Number 1/2016 concerning the mediation procedure in court on economy sharia in Blitar Religious Court, together with the obstacles and solutions.

\section{B. METHODS}

The approach used in this study is qualitative approach. Qualitative research is the procedure of research producing descriptive data in the form of written words or oral from people or behavior which can be observed, in this case the Mediators. In addition, qualitative research is intended to investigate the manner deeply and widely (Ambert at.all, 1995). Besides, it is also an approach or method to explore and understand central symptoms (Raco, 2010) which happened in Blitar Religious Court related to the implementation of Supreme Court Regulations Number 1/2016 concerning Mediation Procedure at Court.

This current research describes all descriptive data or circumstances taken from the subject research about Implementation of Supreme Court Regulations Number 1/2016 concerning Mediation Procedure in the Court in Blitar Religious Court especially in the economy sharia dispute. The data are then analyzed and compared based on theory of sharia economy which has been set up. The finding is expected to update information which can be used as the development of science knowledge and can be applied to resolve various problem related to alternative settlement of dispute as the main authority of Religious Courts dealing with civil problem especially economy sharia dispute.

Descriptive research, in general is a research activity which is directed to figure out or look into some event or phenomena systematically, factually, and accurately. According to Zainal Arifin, qualitative research is a research done in a reasonable and natural manner according to the objective condition in the field without any manipulation, and the type of data collected is in the form of qualitative data (Arifin, 2011).

KHATULISTIWA: Journal of Islamic Studies Vol. 9. No. 2 September 2019
DOI: https://10.24260/khatulistiwa.v9i2.1481-

The Implementation of Supreme Court Regulation... 
This current research is conducted at Blitar Religious Court, East Java. This location is determined based on the consideration that in this location the case of sharia economy dispute breaks up and it is possible to obtain information about the implementation of mediation as the main authority of Religious Court to run the Regulation of Supreme Court Number 1/2016 concerning the Procedure of Mediation at Court.

The data collection employed is observation, in-depth interview, and document study. The nature of the analysis in qualitative research is decomposing the existing phenomena descriptively along with the interpretation of the meaning behind the visible phenomena (Mappiare, 2009). In this study the researchers conduct interpretive analysis by relying on the researchers' imagination power, intuition, and the creative power in the reflective process to capture the meaning of the research object. The purpose of the analysis is to find the meaning of the events which exist in the research object and interpret the meaning. The data obtained from this current research are about mediation of sharia economy dispute in Blitar Religious Court based on PERMA Number 1/2016 which are then analyzed and interpreted into words or explanations which later presented in writing in the form of research reports. The data analyzing process includes data collecting, data editing, data reduction, data display, data verification, and data conclusion (Tanzeh, 2004).

\section{RESULT AND DISCUSSION}

\section{The Implementation of Supreme Court Regulation Number 1/2016 concerning}

\section{Procedure for Mediation in Sharia Economic Disputes in Blitar Religious Court}

The State of Indonesia was founded by the founders of the nation with the ideals of upholding the state based on the law and is confirmed in the 1945 Constitution Article 27 paragraph (1) stating that "All citizens are equal before the law and the governance and are obliged to uphold the law and governance without any except". Based on Article 27 paragraph (1) the 1945 Constitution shows the state gives a guarantee of equal status for every citizen before the law. The guarantee in question is justice for all Indonesian people without any discrimination.

KHATULISTIWA: Journal of Islamic Studies Vol. 9. No. 2 September 2019
DOI: https://10.24260/khatulistiwa.v9i2.1481-

The Implementation of Supreme Court Regulation... 
Christopher W. Moore asserts that mediation is an intervention in negotiations. He stated, "The intervention in a negotiation is that the party has limited or no authoritative decision making power, but assist the most involved in voluntarily reaching a mutually acceptable settlement of issues in dispute".

One of the objectives of the change of PERMA Number $1 / 2008$ to be PERMA Number $1 / 2016$ is in the context of bureaucratic reform of the Supreme Court of the Republic of Indonesia which is oriented to the vision of the realization of a great Indonesian judicial body. One of the supporting elements is mediation as an instrument to increase public access to justice of which principle is administering simple, fast and lowcost process of justice.

Here Article 3 paragraph 6 PERMA Number 1/2016 has also been applied in which the mediation process of sharia economic disputes lasted for 30 days, starting from receiving the notification of the temporary decision from the High Court or the Supreme Court. The principle applied in mediation is closed, in which all of the results of the conversation in the mediation room will be kept secret and even all personal records can be deleted.

It can be said that Blitar Religious Court has handled sharia economic issues applying Facilitative mediation which is also called interest-based mediation. The facilitative mediation has several principles, among others are the structured process, emphasizing the needs and interests of the parties, mediator direct negotiations into interest-based negotiation with mutually beneficial resolution objectives, and the mediator should understand mediation processes and techniques to be able to direct the disputing parties to seek resolution.

Article 6 Paragraph 4 PERMA Number 1/2016 has explained that the parties must attend the mediation process, unless the parties may represent with reasons set out in PERMA. So far based on information obtained from the results of data mining, there are many parties who represent the mediation process to the attorney because they are abroad. But in the case of sharia economic disputes, both parties are willing to attend the mediation that has been ordered. Let's see the cases or dispute involving sharia financial institutions with its customers.

DOI: https://10.24260/khatulistiwa.v9i2.1481-

The Implementation of Supreme Court Regulation... 
Bank Syariah Mandiri in its contract will provide a hajj bailout to customers, where the customer will pay the installments every month. When a dispute occurs, both parties feel the action they have done is in accordance to their mutual agreement. But in fact, after a few months the contract was implemented it turned out that the customer felt he had been harmed by the bank.

The new regulation in PERMA states that the mediator can claim that both parties or one of them is not in good trust during the mediation process. In Blitar Religious Court it has never been stated. After tracing one of the causes of the mediator stating this matter is in accordance to Article 7 Paragraph 2 letters a, b, and $c$ in which the parties are not present after being called appropriately 2 times in a row at a mediation meeting without any apparent reason, or when there are parties who attend the first mediation meeting but never attend the next meeting even though they have been called appropriately without any clear reason, or repetitive absences which ultimately disrupt the mediation schedule. This is a separate obstacle for mediators in seeking peace because one party does not have good intentions. Although it is their problems, the lack of cooperative may constrain the dispute resolution process.

The principle that is always put forward by the Blitar Religious Court is the process of trial which are fast, simple and low-cost. In this process, a fee is needed because it involves several parties and the costs needed are to call the parties to proceed in court. Because it uses the services of a non-judge mediator, the payment system is also inevitably separate from the cost of the case. This is what makes the cost of the mediation process be separated from litigation process. In PERMA, it has been regulated that the obtaining fees from parties for the costs of non-judge mediator services must be in accordance to the agreement of the parties. However, as a matter of fact many parties still question the fee even though an agreement has been made for the mediator service fee. If the mediaiton service fee is included in the court fee it is a violation, because the cost of calling the initial mediation is only the cost of calling for the first session and the fees for the mediator service cannot be included in the cost of the fee. However, because the mediator here is a non-judge mediator, the costs incurred are withdrawn separately.

KHATULISTIWA: Journal of Islamic Studies Vol. 9. No. 2 September 2019
DOI: https://10.24260/khatulistiwa.v9i2.1481-

The Implementation of Supreme Court Regulation... 
The researcher proposed that this fee should be integrated into one -payment system, in which one of the parties will pay two payment, the down payment fee and the cost of mediator services. In addition, the costs incurred are in charge of the Plaintiff/Applicant.

The main actor in the mediation process in addition to the parties involved in the sharia economic dispute is the BSM and the KBIH coordinator, and the key actor in the mediation process, namely the mediator. The mediator serving in Blitar Religious Court especially in this sharia economic dispute has a mediator certificate. The certificate is obtained after participating and has passed in the mediator certification training. The certification of the mediator is held by an institution that has obtained accreditation from the Supreme Court. However, Blitar Religious Court still uses the services of a judge mediator when conducting a round court, considering that the number of non-judge mediators is insufficient. But in the case of the sharia economy, the parties of the dispute prefer non-judge mediators. Based on the interviews and observations it is known that the mediator has carried out his function as a mediator such as explaining the intention, purpose, and nature of mediation to the parties, introducing himself, explaining the position and role as a neutral mediator who do not have the authority to make decisions. The mediator also provides an opportunity to convey problems and proposals, assist the parties in making and formulating a peace agreement, and reporting the results of mediation to the Judicial Examining Judge.

Becoming a mediator of sharia economic disputes require extensive knowledge, especially in the field of sharia economic law. The knowledge possessed by a mediator is not only knowledge in the field of general civilization. However, in a court it is rarely found mediators who can handle Islamic economics cases. Most mediators have been experienced in carrying out civil cases, such as matters of marriage. The mediators in carrying out their duties should act freely and independently without influence from the third parties (service providers, Mediation facilities, organizations or institutions) which have a purpose to influence the independence of the Mediator.

KHATULISTIWA: Journal of Islamic Studies Vol. 9. No. 2 September 2019
DOI: https://10.24260/khatulistiwa.v9i2.1481-

The Implementation of Supreme Court Regulation... 
The pre-mediation stage is one of the stages that should be carried out as explained in Article 17-23 PERMA Number 1/2016 concerning Procedure for Mediation in Courts. In the pre-mediation stage there are several things such as the obligation of judges to examine cases, the obligation of legal counsel, the rights of the parties to choose mediators, the deadline for selecting mediators, calling of parties, and finally parties who do not have good intentions.

This process must be maximized because it affects the next stage. In the premediation case before ordering the parties to take mediation judges must first explain the purpose and benefits of mediation, the obligation of the parties to attend mediation, the costs incurred in the mediation process, and the agreement of the signatory to the mediation explanation form. The fact is that in the Blitar Religious Court there was already a form explaining that the parties had received an explanation of the mediation. On the contrary, when the mediator asked the parties about the explanation of the mediation, the answer of the parties is that they had not received an explanation. What makes the parties do not have a definite goal when taking mediation is because the parties do not understand the mediation. In the economic disputes what occurs between the parties is that they are setting aside the mediation process. In addition, the mediator who does not fully master the case, the image that the litigation process should end in the trial process still firmly embedded in their thinking. Even if the parties can resolve this case at the mediation, both parties may get benefit. The parties can shorten the process, save costs, and even the solutions provided will be in accordance to the wishes of the parties.

Besides the pre-mediation process, in sharia economic disputes what must be carried out is the selection of mediators by the parties as stated in article 19 PERMA Number 1/2016. In the Blitar Religious Court itself, the selection of mediators was carried out with a form of mediator agreement. Although the time limit for selecting mediators is not more than two days, here in one day the parties have already chosen a mediator when the mediation process is carried out. After they agreed, the chief judge of the case examiner issued a decree containing the order to mediate and appoint the mediator concerned. Then the case examining judge must postpone the trial process to provide an opportunity for the party to take mediation. It is the point when the mediation process begins. So the mediator's role is needed to complete the mediation process in sharia economic disputes.

DOI: https://10.24260/khatulistiwa.v9i2.1481-

The Implementation of Supreme Court Regulation... 
Actually, according to PERMA, after issuing a mediator's determination, the mediator decides the day and date of the mediation meeting. Then the case examiner judge through the clerk called the parties to attend the mediation meeting with the help of the bailiff. However, usually the parties soon after the first trial they immediately wanted the mediation process begins at that same day, and without being called for mediation, they were present and carried out the mediation process in front of the mediator.

The call (relaas) of the parties in the sharia economic dispute in the Blitar religious court is a basic element which determines the smooth examination of a case. A call is a process of hearing proceedings that must proceed according to a predetermined procedure. Trial examinations are at the first level in the District Court or in the Religion Court, the appeal level is at the High Court, and the Cassation level is at the Supreme Court which begin with the calling process (or commonly called a call) and notification. The summons of the defendant must be properly carried out. After making a bailiff call, you must submit a message (relaas) to the judge who will examine the case which is evidence that the defendant has been called (Martokusumo, 2002).

Relaas is the summons which becomes the contents of the exploot (Musthofa, 2005). In mediating sharia economic disputes, the mediator also has the authority to summon the parties through a mediation call. Meanwhile calls in civil law is to put in the (official) and inappropriate (properly) to the parties involved in a court case in order to meet and implement the requested points and instructed by the judges or courts (Harahap, 2005). Calling appropriately means the person concerned has been summoned by being called according to the Law, in which the summons is carried out by the bailiff by making the minutes of the summons given to the parties or his legitimate representative considering the necessary deadline and is not less than three working days (Sutantio \& Winata, 2002).

The next stage after passing the pre-mediation stage in sharia economic disputes is the mediation process itself. This stage is one of the keys to the success of the parties to discuss their problems. At this time one party must submit the case resume to the other party. However, at present, the case resumes as described in PERMA Number 1/2016 cannot be applied due to the fact that the parties, when being asked by the mediator about the mediation schedule, they always expect mediation in that day.

DOI: https://10.24260/khatulistiwa.v9i2.1481-

The Implementation of Supreme Court Regulation... 
So that there is no opportunity for the parties to explain the resumes they offer because they feel more comfortable when answering verbally. Actually, this resume can actually be anticipated by providing a separate form so that they may write the offer or the proposal. The benefit is that when the opposing party gets a summons and they get a copy of the lawsuit they will know the posita and petitum submitted. It means that when heading to the mediation room they already have an offer for another party in front of the mediator.

The mediation process in Islamic economics is basically the same as the other disputes which are aimed at achieving islah or peace so that the issues discussed will result in an agreement. If the mediation succeeds in reaching an agreement, the parties can make it separately or be assisted by a mediator who must formulate a written agreement as proof that both parties have achieved a deal. The most important thing in the agreement is not to harm third parties, against the law, public order and decency. Even this agreement can be submitted to the panel of judges which is then strengthened by a peace act. Here there are many cases have been successfully resolved and many peace agreements have been made, and they even agreed to revoke the case and declare the case is closed. However, when the sharia economic dispute is rolling, both parties prefer to take the trial route rather than being resolved at the mediation table. The mediator has made every effort so that the two parties will continue to reconcile given that the trial process will be quite long and take a longer time.

If the mediator cannot reconcile in its entirety, then the next alternative is to try to reach a peace agreement in part. Partial peace agreement was made on a part of the dispute and some of the disputes are continued to the trial. In Blitar Religious Court, it is more likely to lead to partial peace even though the quantity is not too much. But at least the existence of this system facilitates the work of judges in examining cases. Because there is no guarantee that the judge's decision provides justice to the parties. It means that when something can be resolved peacefully, why it should be resolved at the trial. But if indeed there are nothings can be discussed, it is inevitable that the path will be taken through litigation.

KHATULISTIWA: Journal of Islamic Studies Vol. 9. No. 2 September 2019
DOI: https://10.24260/khatulistiwa.v9i2.1481-

The Implementation of Supreme Court Regulation... 
In addition to partially successful mediation reports, the mediator can also report that mediation is unsuccessful or mediation cannot be carried out. The unsuccessful results still dominate Blitar Religious Court, especially in the case of sharia economic dispute. When the mediation period has been determined for 30 days and the parties remain adamant to continue the claim, the mediator must declare and notify the results to the judge reviewing the case. When it has been reported by the mediator, the judge reviewing the case will determine the schedule of the next hearing in accordance to the applicable procedural law.

The mediation was indeed an obligation of everyone who litigated in court, especially in cases where there were sharia economic disputes that occurred for example, between the KBIH coordinator and BSM in Blitar District. The main legal basis for mediation is PERMA Number 1 /2016, about the Mediation Procedure in the Court. In addition, it is in accordance to applicable civil procedural provisions, Article 254 Regulations on Procedural Law and Article 130 of the Indonesian Regulations to encourage parties to pursue a peace process that can be utilized through mediation by integrating into litigation procedures at the Court.

Types of cases that must take mediation, according to Article 4 PERMA Number 1/ 2016 are cases of resistance or resistance of the third parties. So basically the case which must be mediated is a case that has an opponent. So far, the cases in Blitar Religious Court are still dominated by family law cases. Dealing with the case that was submitted to the Blitar Religious Court but after being resolved outside the court with the help of a local mediator who had obtained a certificate and later stated that the mediation was unsuccessful, no further mediation is needed. In addition, for counter-claims (reconciliation) cases, mediation is not necessary.

Because mediation is a closed settlement, it maintains the confidentiality of the parties. Blitar Religious Court has also provided mediation room as a sort of facilities provided so that when the mediation process takes place the parties and mediators can talk comfortably and also intensely when the economic cases go through the mediation process, with the hope that there are no things that need to be covered because there is no way other parties will know their case.

DOI: https://10.24260/khatulistiwa.v9i2.1481-

The Implementation of Supreme Court Regulation... 
Because information from both parties is needed so that the mediator knows in more detail the origin of the sharia economic problem so that the mediator will find it easier to find a solution to the problem. In addition, even though in PERMA this is specifically stated in article 5 paragraph 3 , it is stated that there was a mediation meeting with long-distance audiovisual communication media that allowed all parties to see each other and hear directly and participate in meetings. In Blitar Religious Courts, face to face mediation is preferable. When the parties to the sharia economic dispute undergo a mediation process, the mediator still wants to meet face to face with both parties although one party was reluctant to attend the second mediation process.

There is also a party who use video calls or telephone calls only when one of the parties is abroad and at that time he was represented by his lawyer and that was considered as a direct presence.

Article 7 PERMA Number 1/2016 states that the parties must take mediation in good will. In this article it is explained in detail the factors which can be said to be of good will. However, until now Blitar Religious Court mediator has never stated that the parties were not in good will. One of their reasons related to this matter, although there are parties who fall into the category of not having good intentions, is that in Blitar Religious Court there was no call for mediation at the time, so the mediator had no basis to declare the parties. But this year all mediators can be summoned as long as they are needed. Because one of the categories said to be in good will is having been called appropriately twice in a row at a mediation meeting but he was not present. This is the factor why there are no reports that there is no good intention.

Juridically based on the provisions of article 390 HIR and Article 2 paragraph (3) RV it is stated that the call must be made in writing and not justified through oral because it is difficult to prove its validity. It means that a call will be said to be valid if it is made in writing by the provisions contained in the call which must be original and signed by an authorized officer, with the authority of the authenticity of a certificate, a document or letter. This is one thing that need to be considered, considering that they are present in the mediation process not based on the call of the mediator, but only verbally agreeing on the mediation process.

DOI: https://10.24260/khatulistiwa.v9i2.1481-

The Implementation of Supreme Court Regulation... 
In addition, the party who plays a role in the mediation process is the mediator. The mediator must have a mediator certificate, and they have fulfilled these requirements. However, Blitar Religious Court sometimes also uses judge mediators because the number of non-judge mediator is limited. In carrying out duties as a mediator in Blitar Religious Court, the function has been carried out as usual, but from the functions described in Article 14 some task has not been carried out by mediators such as arranging a timetable for mediation with the parties, filling out the mediation schedule form, and stating that one of the parties is not in good will.

Relating to arranging the mediation schedule, it is indeed carried out verbally so that the filling of the mediation schedule form has also not been fulfilled. In relation to the determination of the parties or parties not having a good will, the exact causes have been explained beforehand.

It can be said that the method used to handle sharia economic disputes between the BSM and the Hajj coordinator is in the form of Settlement Mediation or compromise mediation which aims to produce a compromise of the demands of the parties in conflict. In this mediation model, the mediator has a role to determine the "bottom list" and persuasively encourages the parties to reach the point of compromise. Usually, mediators in this model are high-status mediators and do not emphasize expertise in mediation processes or techniques (Abbas, 2009).

The mediator of Blitar Religious Court did have a different view of the premediation and mediation process in dealing with sharia economic disputes. In an interview with Mr. S it was known that there was something called pre-mediation, but implicitly based on the mediation files obtained the process really depends on the situation. Actually, the pre-mediation consists of the obligation of the judge to provide explanations to the parties, the obligation of the attorney, the right of the parties to choose a mediator, the deadline for selecting mediators, the calling of the parties, and the legal consequences of those who have no good intentions.

Mediators are not allowed to submit any information or documents used during mediation to anyone who is not the parties of the mediation, except there is the written consent of the Parties; or if it is at the request of the court or an obligation under the law and concerning public order; or a sovereign, when the information or documents or the -

DOI: https://10.24260/khatulistiwa.v9i2.1481-

The Implementation of Supreme Court Regulation... 
identity of the parties are not publicized (unless the Parties agree to make it publicized), and is used for research, statistics, accreditation, or education (the Indonesian Mediation Center, article 6).

Discussing the judge's obligations as stated in Article 17, actually this can only be known in the courtroom. Besides by looking at the report given it is known that there is no evidence of an explanation of mediation. The judge is only ordering mediation without explaining the benefits, objectives, costs, and obligations of the parties in the mediation process. In relation to using lawyers to represent the parties, some may agree, but the others do not. In fact, in Article 18 PERMA it is explained that legal counsel must assist parties to mediate. Even when the principal cannot attend directly, the attorney also continues to work on this process to reach an agreement. For other pre-mediation, this might be related to the calling of the parties which is still a separate obstacle. Something still happens dealing with the explanation of the legal consequences of those who were declared to be in good will. Article 22 clearly states this condition even though it is still in a new category, but the existence of this rule has an impact that mediation which is not only a formality but also a fairly good method of resolving cases through deliberation. Referring to the applicable rules and regulations, the process that occurs between the BSM and the KBIH coordinator is in accordance to the lawsuit that the Plaintiff and Defendant use a wadiah yad dhomamah contract in which the customer's deposit paid to the KBIH coordinator can be utilized if the responsibility is clear. In fact, in the view of the Defendant as the party that receives monthly installments from the customers, the cost of the hajj bailout is not paid in accordance to the agreement. This is the beginning of the arouse dispute and a mediation point is needed. Since the case of Islamic economics has its own characteristics, it requires mediators who have scientific knowledge in the field of Islamic economics.

\section{The obstacle of the Implementation of Supreme Court Regulation Number 1/2016 concerning Procedure for Mediation in Sharia Economic Disputes in Blitar Religious Court}

Principles or philosophies are the frameworks which must be known by the mediator so that in carrying out the mediation he does not come out of the direction of the philosophy behind the foundation of the mediation institutions (Hoynes, at.all, 2004).

KHATULISTIWA: Journal of Islamic Studies Vol. 9. No. 2 September 2019
DOI: https://10.24260/khatulistiwa.v9i2.1481-

The Implementation of Supreme Court Regulation... 
Basically the mediator has tried to carry out the mediation process. But there are constraints have been found in the process of research which needs to be fixed by the institution concerned. The constraints are such as: (1) Technical Factors: inequality between the policies of the Chief of Court and PERMA, mediation time, the background of the mediator, mediator service fee, lack of coordination between mediators, resume case, mediation call (Mujahidin, 2008; Arto, 2005), mediation facility, mediator discipline, mediation schedule, and there is no pre-mediation Process; (2) Non-Technical Factors: lack of understanding about the importance of mediation, the influence of outsiders to avoid the mediation process, absence of one party, unwilling to make reconciliation, and the desire to complete the litigation process (Sutiyono, 2008).

\section{The solution to Supreme Court Regulation Number 1/2016 concerning Procedure for Mediation in Sharia Economic Disputes in Blitar Religious Court}

In the information age as it is today the efficiency and effectiveness in various fields is a necessity which includes the settlement of cases submitted in religious courts. This is in accordance to the principle of civil law which must be carried out in a simple, fast and low-cost manner. In practice, the justice seekers want and need the process of settlement of cases which is carried out quickly and formally or informally procedure and can be put into motion quickly (Saifullah, 2007). Therefore, in the amidst of information age and increasingly sophisticated globalization, religious courts inevitably must participate actively in digital civilization, by the utilization of telecommunications technology and information maximally, both in the administrative process and in settling cases.

Thus, there are four basic things in relation to the mediation process, namely the existence of disputes that must be resolved, settlement through negotiations, the purpose of negotiations to obtain an agreement, and the role of the Mediator in assisting the settlement. This is what is needed in the resolution of the main dispute that has been integrated with the Court.

Based on the constraints that have been presented in the process of sharia economic dispute mediation based on PERMA above, possible solutions can be offered from both technical and non-technical factors. First, there must be special educational and training of mediators associated with the sharia economic disputes.

DOI: https://10.24260/khatulistiwa.v9i2.1481-

The Implementation of Supreme Court Regulation... 
After sharia economic disputes become the authority of the Religious Court, the mediator must also learn matters relating to Islamic economics. Not only the judges but the mediator must also have these skills in order to make the mediation easier to provide solutions when sharia economic disputes occur.

Second, integrating or adopting PERMA rules in the Chief of Court's Policy. The dispute resolution process through ADR (Alternative Dispute Resolution) is not something new in the nation's cultural values, because the nature of Indonesian society is known for its familial and cooperative nature in solving the problem. In various ethnic groups in Indonesia usually they have used the deliberations and consensus settlement method to make decisions. After the integration of the ADR process into the mediation in the court, adjustments are needed as what has been set in PERMA.

Third, the judge examining cases may not set up the next hearing before getting the report of results from the Mediator. Although the provisions of the mediation period is about 30 working days, sometimes when the mediation process has not yet been completed, they have already been called to carry out the next trial process. This is what often happens. Consequently, there is a clash of time for the mediation and the trial. Fourth, the Chairperson of the Court must be more careful in selecting the mediators, not only due to the ownership of the mediator's certificate but also considering his work experience. Fifth, it is advisable for the mediator service fee to be included in the upfront fee of the case based on the policy of the Court Chief, so that a one-pay system will apply. One-pay system is a solution offered by researchers, since in fact during the mediation the mediator in charge is a non-judge mediator so that the costs incurred are in accordance to the agreement. Anyway there are a lot of complaint dealing with such additional costs. Because the mediator in the Blitar religious court is incorporated in AMIRPA (Mediator Association), the fees charged to the parties must be the same. So according to researchers, it is better to use a one-time payment system which is included in the case down payment.

Sixth, the Mediator should have an agenda for evaluating the mediation process that has been carried out and the problems that arise. Actually, according to AMIRPA there was an evaluation to its member mediators. In this case, the agenda is not only conveying aspirations but also correcting and evaluating, so that when different problems occur, they can solve the problem.

DOI: https://10.24260/khatulistiwa.v9i2.1481-

The Implementation of Supreme Court Regulation... 
Seventh, the Mediator must be more active in coordinating with the court in enforcing the rules in PERMA. Eighth, related to a blank resume, it should be created a separate case at the first session. So before entering the mediation room the Defendant / Respondent already have an idea or an offer.

The resume of the case has actually been arranged in PERMA. The researcher propose the case resume was applied like a form/witness form which had been carried out by the court. Actually, when the parties were called by the bailiff certainly it has been enclosed with the lawsuit plaintiff /applicant.

Ninth, the first call to the parties should not be in the form of a summons but a mediation call. One of the obstacles to apply PERMA rules regarding to the determination of parties/parties is that there is no good intention. So the absence of the parties in the mediation process can be used as basis of the statement that there are parties who do not have good will in mediation. In accordance to the procedural law, the first call of the agenda is mediation. So it is better if it is indeed inapplicable, the bailiff also attaches a mediation call so that the costs and time are saved. Tenth, In relation to facilities for mediation, sometimes it burdens the court funds. But if the costs of mediation are included in the case, the court does not need to be confused about the lack of funds. If the facilities are comfortable, conditioned, complete, the mediation process can run well.

Eleventh, the code of conduct should be strongly applied to the mediator, so that the process can avoid unexpected behaviors which possibly happen. Twelfth, the mediation schedule should be determined at the beginning of the meeting so that the parties are participating and both the parties and the mediator take an active role in this process. The pre-mediation process may be implemented if there was an agreement with the parties to schedule a mediation. This is what needs to be applied if the parties have received an appropriate call to be present at the mediation process. Therefore, an agreement will certainly occur because they knew their agenda at the first trial. So that when they violate their own schedule they also have an impact on their trial process too.

Thirteenth, optimizing Pre-Mediation. This pre-mediation needs to be applied in the court. When the pre-mediation is successfully implemented, surely little by little the problems or obstacles that have been described by the researcher above can be overcome. Fourteenth, the Judges examining the case must be more intense in promoting mediation to the parties.

DOI: https://10.24260/khatulistiwa.v9i2.1481-

The Implementation of Supreme Court Regulation... 
The reason why they were reluctant to participate in mediation is because they might not know the mediation. Fifteen, lawyers or other parties involved must also be given an awareness to support the importance of mediation so that the prior dogmas embedded in the view of litigants can be resolved.

Sixteenth, executing KMA (Decision of the Chief of the Supreme Court) command on the granting attendance costs of the defendant/respondent in the mediation process which are charged to the Plaintiff/Applicant, the cost should be included into the case payment. According to KMA, the costs given to the Defendant/Respondent is to make them come in the mediation process. This sometimes becomes an obstacle. When their presence is valued by giving the arrival costs, the opposing parties do not feel disadvantaged when there is common agreement or deal in the mediation meeting. Seventeenth, the mediator must be more active in explaining the benefits and objectives of the process by means of mediation, as well as explaining to the parties the benefits if the case is resolved via the non-litigation process.

\section{CONCLUSION}

The mediation in sharia economic disputes in Blitar Religious Court has implemented PERMA Number 1/2016 concerning Procedure for Mediation in Courts since March 2016. There are two non-judge mediators serving in Blitar Religious Court. All mediators have passed and obtained a mediator certificate. It can be concluded that Blitar Religious Court has implemented several rules stated in this PERMA. But there are some aspects which have not been implemented such as case resumes, ongoing mediation reluctance, the pre-mediation process which has not been maximized and the success rates which are still low. However, there are some developments which are still better than before, such as the existence of successful mediation, which is increased compared to the previous year. In addition, the court has also provided adequate facilities. In addition, the mediation costs here have been set at Rp. 125,000.00 which is in accordance to the provisions of the AMIRPA. In Blitar Religious Court, the mediator stated that sharia economic matters were declared unsuccessful if the parties remained at their own stand and there were different views on the dispute so that the mediator could not provide a maximum solution.

DOI: https://10.24260/khatulistiwa.v9i2.1481-

The Implementation of Supreme Court Regulation... 
The constraints in implementing PERMA Number 1/2016 concerning Procedures for Mediation in Courts in sharia economic disputes in Blitar Religious Court are due to the technical and non-technical factors. In technical factors there is inequality between the policy of the court chief and PERMA, mediation time which is not fully utilized, the mediator background, the mediator service fees, lack of coordination between mediators, case resumes, lack of mediation facilities, mediators' punctuality, absence on mediation schedules, and non-optimal pre-mediation. Dealing with non-technical matters, in general, they experience such problems as the mediator, the lack of understanding of the parties about the importance of mediation, the influence of outsiders to negate the mediation process, the absence of one party, unwillingness to reconcile, the desire to complete the litigation process.

Possible solutions can be proposed for both technical and non-technical factors. They are the implementation of special mediator training specifically related to sharia economic disputes; integrating or adopting PERMA rules into the Court Chief 's Policy; the case examiner judge should not determine the next trial day but waiting for the report of the Mediator; the chief of the court must be more careful in selecting the mediators; mediator service costs should be included in the cost of the down-payment cases (one-pay system); the evaluation of mediation by the mediator; the mediator must be more active in coordinating with the Court; providing Resume Case Form; providing mediation relaas; the accessibility of mediation must be optimized; optimizing the Mediator Code of Conduct; the fix mediation schedule; optimizing premediation process; the case inspector must more intense to explain to the parties about mediation; the lawyer or other parties involved should also be given an explanation of the importance of supporting mediation; executing KMA command on granting the cost of participation of the defendant/respondent; the mediator must be more active in explaining the benefits and objectives of the mediation.

KHATULISTIWA: Journal of Islamic Studies Vol. 9. No. 2 September 2019
DOI: https://10.24260/khatulistiwa.v9i2.1481-

The Implementation of Supreme Court Regulation... 


\section{BIBLIOGRAPHY}

Abbas, Syahrizal. 2009. Mediasi dalam Perspektif Hukum Syariah, Hukum Adat dan Hukum Nasional, Jakarta: Kencana.

Abdul Manan. 2005. Penerapan Hukum Acara Perdata di Lingkungan Peradilan Agama, cet3, Jakarta: Kencana.

Ambert, Ann Marie, Patricia A. Adler, Peter Adler and Daniel F. Detzner. 1995. Understanding and Evaluating Qualitative Research, Vol. 57 No. 4, November.

Arifin, Zainal. 2011. Penelitian Pendidikan Metode dan Paradigma Baru, Bandung: RosdaKarya.

Arto, Mukti. 2005. Praktek Perkara Perdata Pada Pengadilan Agama cet. VI; Yogyakarta. Pustaka Pelajar Offset.

Dokumen putusan No. 3333/Pdt.G/2014/PA.BL

Fuady, Munir. 2003. Arbitrase Nasional: Alternatif Penyelesaian Sengketa Bisnis, Bandung: PT. Citra Aditya Bakti.

Harahap, M. Yahya. 2004. Tinjauan Sistem Peradilan dalam Mediasi dan Perdamaian Jakarta: Mahkamah Agung RI.

Harahap, M. Yahya. 2005. Hukum Acara Perdata, Jakarta: Sinar Grafika.

Hoynes, John Michael, Cretchen L. Haynes, dan Larry Sun Fang. 2004. Mediation: Positive Conflict Management, New York: SUNY Press.

Mahkamah Agung RI, 2004. Mediasi dan Perdamaian, Jakarta: Mahkamah Agung RI.

Mahkamah Agung RI, Nomor 1 Tahun 2016 tentang Prosedur Mediasi di Pengadilan.

Mappiare AT, Andi. 2009. Dasar-dasar Metodologi Riset Kualitatif untuk Ilmu Sosial dan Profesi, Malang: Jenggala Pustaka Utama.

Martokusumo, Sudikno. 2002. Hukum Acara Perdata, Yogyakarta: Liberty.

Moore, Christopher W. 1996. The Mediation Process: Practical Strategies For Resolving Conflict, San Francisco: Jossey-Bass Publisher.

Mujahidin, Ahmad. 2008. Pembaharuan Hukum Acara Perdata Peradilan Agama dan Mahkamah Syar'iyah Di Indonesia, Jakarta Pusat: Ikatan Hakim Indonesia IKAHI.\

KHATULISTIWA: Journal of Islamic Studies Vol. 9. No. 2 September 2019
DOI: https://10.24260/khatulistiwa.v9i2.1481-

The Implementation of Supreme Court Regulation... 
Musthofa. 2005. Kepaniteraan Peradilan Agama, Jakarta: Prenada Media.

Pasal 49 huruf i Undang-Undang Nomor 3 Tahun 2006 Tentang Perubahan Atas UndangUndang Nomor 7 Tahun 1989 Tentang Peradilan Agama

Poerwadarminta, W.J.S. 1985. Kamus Umum Bahasa Indonesia, cet. 8, Jakarta: P.N. Balai Pustaka

Pusat Mediasi Nasional (the Indonesian Mediation Center), Kode Etik Mediator, dikutip dalam www.pmn.or.id

Pusat Mediasi Nasional (the Indonesian Mediation Center), Kode Etik Mediator, dikutip dalam www.pmn.or.id Pasal 6.

Raco, J.R. 2010. Metode Penelitian Kualitatif Jenis, Karakteristik dan Keunggulannya, Jakarta: PT Grasindo.

Saifullah. 2007. Refleksi Sosiologis Hukum, Bandung: Reflika Aditama.

Sutantio, Retno Wulan, dan Iskandar Oeripkarta Winata. 2002. Hukum Acara Perdata Dalam Teori dan Praktek, cet.9 Bandung: Mandar Maju.

Sutiyono, Bambang. 2008. Hukum Arbitrase dan Alternatif Penyelesaian Sengketa, Yogyakarta: Gama Media.

Tanzeh, Ahmad. 2004. Metode Penelitian Praktis, Jakarta: PT. Bina Ilmu.

Umam, Khotibul. 2010. Penyelesaian Sengketa di Luar Pengadilan, Yogyakarta: Penerbit Pustaka Yustisia.

Undang-Undang Nomor 30 Tahun 1999 tentang Arbitrase dan Alternatif Penyelesaian Sengketa

KHATULISTIWA: Journal of Islamic Studies Vol. 9. No. 2 September 2019
DOI: https://10.24260/khatulistiwa.v9i2.1481-

The Implementation of Supreme Court

Regulation... 